University of Nebraska - Lincoln

DigitalCommons@University of Nebraska - Lincoln

Faculty Papers and Publications in Animal

Science

Animal Science Department

2009

\title{
Influence of Corn Hybrid Traits and Processing Method on Nutrient Digestibility
}

Matt K. Luebbe

University of Nebraska-Lincoln, mluebbe2@unl.edu

G. E. Erickson

University of Nebraska-Lincoln, gerickson4@unl.edu

T. J. Klopfenstein

University of Nebraska-Lincoln, tklopfenstein1@unl.edu

W. A. Fithian

Golden Harvest Seeds Inc., Waterloo, NE

Follow this and additional works at: https://digitalcommons.unl.edu/animalscifacpub

Part of the Animal Sciences Commons

Luebbe, Matt K.; Erickson, G. E.; Klopfenstein, T. J.; and Fithian, W. A., "Influence of Corn Hybrid Traits and Processing Method on Nutrient Digestibility" (2009). Faculty Papers and Publications in Animal Science. 767.

https://digitalcommons.unl.edu/animalscifacpub/767

This Article is brought to you for free and open access by the Animal Science Department at DigitalCommons@University of Nebraska - Lincoln. It has been accepted for inclusion in Faculty Papers and Publications in Animal Science by an authorized administrator of DigitalCommons@University of Nebraska - Lincoln. 


\title{
with \\ Influence of Corn Hybrid Traits and Processing Method on Nutrient Digestibility ${ }^{1}$
}

\author{
M. K. Luebbe, ${ }^{*}$ G. E. Erickson, ${ }^{* 2}$ PAS, T. J. Klopfenstein, ${ }^{*}$ and W. A. Fithian† \\ *Department of Animal Science, University of Nebraska, Lincoln 68583; and †Golden Harvest \\ Seeds Inc., Waterloo, NE 68069
}

\section{ABSTRACT}

Two experiments were conducted to determine the effects of corn hybrid and processing method on the site and extent of nutrient digestibility and ruminal fermentation. Treatments consisted of 2 processing methods, dry-rolled corn (DRC) and high-moisture corn (HMC), and 3 hybrids, H-8562 (1), 33P67 (2), and $H$-9230 (3), in a $2 \times 3$ factorial arrangement. In Exp. 1, six ruminally cannulated crossbred steers $(436 \pm 8 \mathrm{~kg})$ were used in a $6 \times 6$ Latin square design. Total tract DM, OM, and starch digestibility $(S T D)$ were greater $(P<0.10)$ for HMC compared with DRC. A hybrid $\times$ processing method interaction $(P<0.10)$ was observed for propionate concentration and the acetate-to-propionate ratio. In Exp. 2, two ruminally and duodenally fistulated steers were used to determine the site and extent of nutrient digestion using the mobile bag technique at 2 ruminal incubation times. Ruminal STD was not different $(P=0.14)$ among hybrids but was greater $(P<0.01)$ for HMC compared with DRC. Postruminal and total tract STD were greater $(P<$

\footnotetext{
${ }^{1}$ A contribution of the University of Nebraska Agricultural Research Division, supported in part by funds provided through the Hatch Act.

${ }^{2}$ Corresponding author: geericks@unlnotes. unl.edu
}

$0.01)$ for hybrids 1 and 3 than for hybrid 2, and were greater $(P<0.01)$ for $H M C$ than DRC. In both experiments the geometric mean diameter and geometric $S D$ were influenced $(P<0.05)$ by both hybrid and processing method. More intense processing methods or selection of hybrids with softer kernels will result in greater digestibility and ruminal propionate concentrations. Digestibility of corn samples can be characterized using the mobile bag technique but particle size can influence results.

Key words: digestibility, finishing cattle, hybrid, processing, starch

\section{INTRODUCTION}

Cattle consuming starch from corn hybrids with desirable kernel traits (e.g., larger and softer kernels, rapid degradation rates) are more efficient than cattle fed hybrids with harder kernels and slower degradation rates (Ladely et al., 1995; Jaeger et al., 2006). A kernel with a softer endosperm is generally thought to have more enzyme-accessible space between starch molecules, which increases the ability of bacteria to attach and degrade kernels to a greater extent (French, 1973). Studies conducted to determine which chemical factors influence ruminal starch digestion have varying results. Dombrink-
Kurtzman and Bietz (1993) found a negative correlation between starch digestibility (STD) and zein protein content, whereas others have found no relationship with the zein protein content (Philippeau et al., 1998). The most consistent properties that have been shown to affect ruminal STD are kernel hardness (Philippeau et al., 1998, 1999a; Correa et al., 2002) and processing method (Corona et al., 2006; Szasz et al., 2007).

Seven different corn hybrids varying in chemical and physical properties were fed in a feedlot performance study to determine the impact of those properties (i.e., starch polymer, kernel hardness) on finishing cattle performance (Jaeger et al., 2006). Larger, softer kernels were found to be significantly correlated with improved feed efficiencies in beef feedlot cattle when fed as dry-rolled corn (DRC). The results from the performance and digestion studies suggest that kernel traits have an impact on starch utilization by feedlot cattle.

Using these data, our hypotheses were that softer kernels would be more digestible and that propionate concentrations of animals fed hybrids with larger and softer kernels would be greater than those consuming smaller and harder kernels. The objectives of this research were to determine total tract nutrient digest- 
ibility of 3 hybrids used by Jaeger et al. (2006) processed as DRC and high-moisture corn (HMC) in an in vivo trial as well as by using the mobile bag technique.

\section{MATERIALS AND METHODS}

The University of Nebraska Institutional Animal Care and Use Committee approved all procedures and guidelines involving animals.

\section{Experiment 1}

Three commercially available dent corn hybrids were selected from a previous study (Jaeger et al., 2006) representing a range in physical and chemical kernel traits. The hybrids consisted of Golden Harvest (Golden Harvest Seeds Inc., Waterloo, NE) H-8562 (1), Pioneer (Pioneer Hi-Bred Int. Inc., Des Monies, IA) 33P67 (2), and Golden Harvest H-9230Bt (3); processed either as DRC or reconstituted $\mathrm{HMC}$ in a $3 \times 2$ factorial arrangement of treatments. Whole corn was dry-rolled using a roller mill and stored in individual bins until fed. High-moisture corn was prepared by dry rolling and reconstituting to $28 \%$ moisture to mimic early harvested HMC. The distance between the rollers on the mill was set so that the spacing was equal for all hybrids. High-moisture corn was stored in oxygen-limiting bags for $120 \mathrm{~d}$ before initiation of the experiment. In a previous study (Jaeger et al., 2006), G:F was $0.185 \pm 0.002$ for hybrid 1, $0.169 \pm 0.002$ for hybrid 2, and $0.175 \pm 0.002$ for hybrid 3. Laboratory analyses for the Stenvert hardness test (weight of hard endosperm retained on a $425 \mu \mathrm{m}$ sieve divided by total sample weight) indicated hybrid 1 had the softest kernels, hybrid 2 was intermediate, and hybrid 3 was the hardest $(20.9,26.1$, and $28.5 \%$, respectively; Jaeger et al., 2006). Additionally, hybrid 1 had the largest kernels as indicated by the 1,000-grain weight $(354.5,332.4$, and $323.3 \mathrm{~g}$, respectively; Jaeger et al., 2006).

Six ruminally cannulated crossbred steers $(436 \pm 8 \mathrm{~kg})$ were used in a 6

\section{Table 1. Composition of diets (\% of diet DM) in Exp. 1 and 2}

\begin{tabular}{|c|c|}
\hline Ingredient & $\%$, DM \\
\hline $\begin{array}{l}\text { Dry-rolled high-moisture corn } \\
\text { hybrid }^{1}\end{array}$ & 68.5 \\
\hline Wet corn gluten feed & 20.0 \\
\hline Alfalfa hay & 7.5 \\
\hline Dry supplement ${ }^{2}$ & 4.00 \\
\hline Finely ground corn & 1.42 \\
\hline Limestone & 1.52 \\
\hline Urea & 0.54 \\
\hline Sodium chloride & 0.30 \\
\hline Tallow & 0.13 \\
\hline Trace mineral premix ${ }^{3}$ & 0.05 \\
\hline Rumensin-80 premix ${ }^{4}$ & 0.02 \\
\hline Tylan-40 premix ${ }^{5}$ & 0.01 \\
\hline Vitamin premix ${ }^{6}$ & 0.01 \\
\hline
\end{tabular}

${ }^{1}$ Hybrids consisted of Golden Harvest $\mathrm{H}-8562$, Pioneer 33P67, and Golden Harvest H-9230Bt; processed as dryrolled corn or high-moisture corn in Exp. 1. Dry-rolled corn hybrid Pioneer 33P67 was fed in Exp. 2.

${ }^{2}$ Supplement formulated to be fed at $4 \%$ of diet DM.

${ }^{3}$ Premix contained $10 \% \mathrm{Mg}, 6 \% \mathrm{Zn}$, $4.5 \% \mathrm{Fe}, 2 \% \mathrm{Mn}, 0.5 \% \mathrm{Cu}, 0.3 \% \mathrm{I}$, and $0.05 \%$ Co.

${ }^{4}$ Premix contained $176 \mathrm{~g} / \mathrm{kg}$ monensin (Elanco Animal Health, Indianapolis, IN).

${ }^{5}$ Premix contained $88 \mathrm{~g} / \mathrm{kg}$ tylosin (Elanco Animal Health).

${ }^{6}$ Premix contained (per g) 1,500 IU vitamin $A, 3,000 \mathrm{IU}$ vitamin $\mathrm{D}$, and 3.7 IU vitamin $\mathrm{E}$.

$\times 6$ Latin square design with $14-d$ periods consisting of a 9-d adaptation followed by a 5 -d collection period. Diets (DM basis) consisted of $68.5 \%$ DRC or HMC corn hybrid, 20.0\% wet corn gluten feed (Sweet Bran, Cargill, Blair, NE), 7.5\% alfalfa, and $4.0 \%$ supplement (Table 1). Diets were formulated to meet or exceed the NRC (1996) requirements for metabolizable protein $(13.3 \% \mathrm{CP})$, Ca $(0.7 \%), \mathrm{K}(0.65 \%)$, and P $(0.4 \%)$. Cattle were adapted to corn grain before the experiment. Diets were fed once daily at $0730 \mathrm{~h}$ for ad libitum intake. Feed refusals were collected on d 9 to 14, weighed, and subsampled.
Steers were individually fed in $1.5 \times$ $2.4 \mathrm{~m}$ slotted-floor pens with rubber mats in a temperature controlled room $\left(25^{\circ} \mathrm{C}\right)$ with ad libitum access to water. Steers were fed in pens during the adaptation ( 1 to 9 ) and moved into stanchions for the 5-d collection period on d 10 .

Feed intake and ruminal $\mathrm{pH}$ were continuously monitored on $\mathrm{d} 10$ through 14 using feed bunks suspended from load cells and submersible pH electrodes, respectively (Cooper et al., 1999; Crawford et al., 2008). Feed intake measurements (d 10 to 14) included DMI, number of meals per day, average meal size, total time spent eating per day, average meal length, and intake rate $(\% / \mathrm{h})$. Meals were determined when feed bunk weights did not change for $20 \mathrm{~min}$. Rate of feed intake was calculated as the slope through the natural log-transformation of feed weights for each steer throughout the day (Erickson et al., 2003). Ruminal pH variables of interest included the average, maximum, minimum, change (maximum to minimum), variance, and time and area below 5.6 (minutes $\times \mathrm{pH}$ units). Continuous $\mathrm{pH}$ measurements were collected using submersible $\mathrm{pH}$ electrodes placed into the rumen during the collection period. Probes were suspended in a stationary position approximately $10 \mathrm{~cm}$ above the ventral floor of the rumen before the collection period. Intake measurements were collected 5 times $/ \mathrm{min}$ and averaged for each minute Ruminal $\mathrm{pH}$ measurements were collected 4 times/ min and averaged for each minute.

Fecal output was estimated by dosing a 7.5-g bolus of chromic oxide twice daily (0700 and $1900 \mathrm{~h}$ ) via rumen cannula on d 7 through 14 . On d 10 through 14, fecal grab samples were collected 3 times daily and immediately frozen. Fecal samples and feed refusals for each steer in each period were composited, freezedried, and ground using a Wiley mill (Thomas Scientific, Swedesboro, NJ) to pass through a 1 -mm screen. Chromium concentration of feces was determined by atomic absorption spectrophotometry using an air- 
acetylene flame according to Williams et al. (1962). Fecal output (g/d) was calculated as chromium bolused $(\mathrm{g} / \mathrm{d})$ divided by the fecal chromium concentration (g/g; Owens and Hanson, 1992).

Ruminal fluid samples were collected during ruminal $\mathrm{pH}$ data collection via the rumen cannula using the suction strainer technique (Raun and Burroughs, 1962) and were immediately frozen. Seven ruminal fluid samples were collected each period on d 14 before feeding and every 2 $\mathrm{h}$ for $12 \mathrm{~h}$. At the completion of the experiment, ruminal fluid samples were thawed to measure VFA concentration using the procedures of Erwin et al. (1961). Ruminal fluid samples were analyzed in a gas chromatograph (Series II, 5890; Hewlett-Packard, Avondale, MA) using a Supelco 12144 column (Bellefonte, PA).

Dry matter content of feed ingredients and feed refusals were analyzed for $\mathrm{DM}$ in a $60^{\circ} \mathrm{C}$ forced-air oven for $48 \mathrm{~h}$. Laboratory DM of feed ingredients, feed refusals, and fecal samples was determined in a $100^{\circ} \mathrm{C}$ forced-air oven for $24 \mathrm{~h}$, and $\mathrm{OM}$ was determined by ashing samples at $600^{\circ} \mathrm{C}$ for 8 h (AOAC, 1995). Nitrogen content of feed ingredients, feed refusals, and fecal samples was determined using a combustion method nitrogen analyzer (Leco FP-528, Leco Corp., St. Joseph, MI) according to the AOAC (1995) procedure. Starch content of feed ingredients, orts, and fecal samples were determined by the procedures of Murphy et al. (1994) using a spectrophotometer (Spectramax 250, GMI Inc., Ramsey, MN).

Rolled HMC (after fermentation) and DRC samples from each hybrid were analyzed for particle size determination. United States Bureau of Standard (USBS) Sieves \#1 $(9,500$ $\mu \mathrm{m}$ screen opening), \#3 (6,300 $\mu \mathrm{m})$,

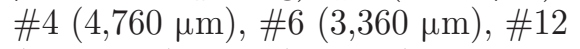
$(1,680 \mu \mathrm{m}), \# 30(590 \mu \mathrm{m})$, and \#70 $(212 \mu \mathrm{m})$ were used for determination of the geometric mean diameter (GMD; $\mu \mathrm{m})$ for each hybrid. The USBS sieves were placed in a Fritsch Analysette wet-sieving device (Model 8751, Fritsch-GmbH, Idar-
Oberstein, Germany) for particle size analysis. The sieves were placed in the following order, from top to bottom, $\# 1, \# 3, \# 4, \# 6$, \#12, \#30, and \#70. Approximately $30 \mathrm{~g}$ of sample (DM) was evenly distributed across the top screen and the cap was secured onto the device. Samples were subjected to a 5-min period of vibration and spray, which moved particles down through the screens. Particles from each separate screen were cleaned onto preweighed filter papers that were dried for $24 \mathrm{~h}$ at $100^{\circ} \mathrm{C}$. Filter papers and sample retained on each screen were weighed after being dried for $24 \mathrm{~h}$ at $100^{\circ} \mathrm{C}$. This procedure was performed in duplicate for the corn samples. The GMD and the geometric standard deviation (GSD) of the samples were calculated by the method described by Behnke (1994). Sample not retained on a screen was assumed to have a GMD of $73 \mu \mathrm{m}$. Additionally, the proportion of sample that was not retained on a screen was calculated to determine the proportion of samples smaller than $212 \mu \mathrm{m}$.

Nutrient digestibility data (Exp. 1) were analyzed as a $6 \times 6$ Latin square design using the MIXED procedure (SAS Inst. Inc., Cary, NC). Animal within period was the experimental unit. The model consisted of animal, period, hybrid, processing method, and the hybrid $\times$ processing method interaction. Animal within period was a random effect. Ruminal $\mathrm{pH}$, intake, and VFA data were analyzed as repeated measures using the MIXED procedure of SAS. Animal within period was the experimental unit. The model consisted of animal, period, time, hybrid, processing method, and the hybrid $\times$ processing method interaction. Time of the 7 observations within a day was the repeated variable for VFA data. Day within collection period was a repeated variable for intake patterns and ruminal $\mathrm{pH}$. The autoregressive structure was used as the covariance structure for VFA, intake patterns, and ruminal pH data (Littell et al., 1998). Least squares means were separated using the least significant difference method when a significant $F$-test $(P<0.05)$ was detected. The model for particle size data consisted of processing method, hybrid, and the processing method $\times$ hybrid interaction. Least squares means were separated using the least significant difference method when a significant $F$-test $(P<0.05)$ was detected.

\section{Experiment 2}

Two ruminally and duodenally cannulated crossbred steers $(790 \pm 13 \mathrm{~kg})$ were used to simulate ruminal and postruminal digestion of corn samples using the mobile bag technique (Voigt et al., 1985; Haugen et al., 2006;

Loveday et al., 2006). Two steers are sufficient for in situ (Vanzant et al., 1998) and the mobile bag technique (NRC, 2001). Corn samples and basal diets were the same as Exp. 1. Steers were limit-fed at $1.8 \%$ of BW once daily at $0700 \mathrm{~h}$ to reduce variability in passage rate and subsequent intestinal transit time. During intestinal bag insertion ( $5 \mathrm{~d}$ ), steers were tethered in individual stanchions. After bag insertion, steers were housed in $1.5 \times 2.4 \mathrm{~m}$ individual slotted-floor pens for $9 \mathrm{~d}$ of rest.

All samples were ground through a $0.625-\mathrm{cm}$ screen to simulate masticated corn samples (Simon, 2001; Macken, 2004). Dry-rolled corn samples were ground as is, and HMC samples were ground frozen to limit DM losses associated with freeze-drying and the effect on the physical form of the sample (Lopez et al., 1995; Philippeau and Michalet-Doreau, 1997). Ruminal incubation times of 30 and $20 \mathrm{~h}$ were calculated from the inverse of passage rate at $3.44 \% / \mathrm{h}$ (Shain et al., 1999). These incubation times represent approximately the mean retention time and $66 \%$ mean retention time, respectively (Klopfenstein et al., 2001). Two Dacron bags $(10 \times 20 \mathrm{~cm})$ for each sample were filled with approximately $6 \mathrm{~g}$ of corn (DM) and incubated in each steer for 20 and $30 \mathrm{~h}$ to determine ruminal degradability of nutrients. Additionally, 25 Dacron bags (5 $\times 10 \mathrm{~cm}$ ) for each sample were filled with approximately $1.75 \mathrm{~g}$ of DM and ruminally incubated in preparation 
for postruminal insertion into the duodenum. All bags were removed from steers after ruminal incubation at the same time and frozen. To simulate abomasal digestion, bags were thawed and incubated in a pepsin and $\mathrm{HCl}$ solution ( $1 \mathrm{~g}$ pepsin/L of $0.01 \mathrm{~N}$ $\mathrm{HCl}$ ) at $37^{\circ} \mathrm{C}$ for $3 \mathrm{~h}$. For $5 \mathrm{~d}, 12$ bags daily were inserted into the duodenum $12 \mathrm{~h}$ after feeding and subsequently were frozen after being recovered in the feces (12 to $24 \mathrm{~h}$ after insertion).

Ruminally and intestinally incubated bags were thawed, along with 4 bags/sample that were not ruminally incubated, and rinsed with $0.325 \mathrm{~L}$ of water per bag for 5 wash cycles using $39^{\circ} \mathrm{C}$ water. The wash cycles consisted of a 1-min agitation and a 2-min spin per cycle (Whittet et al., 2003). The nonincubated bags were used to determine the proportion of residue that was washed out of the Dacron bags without incubation. The rinsed bags were dried using a forced-air oven at $60^{\circ} \mathrm{C}$ for $48 \mathrm{~h}$. Samples were allowed to cool and then were weighed to determine DM disappearance. Two bags per sample were composited to have adequate residue within steer for both the 20- and 30-h incubations for ruminal STD and degradable intake protein (DIP). An average of 21 bags (17 to 25) per corn sample was used to calculate postruminal and total tract DM digestibility (DMD). The mean transit time (time from insertion to appearance in the feces) for bags was $17.3 \pm 3.7 \mathrm{~h}$. Bags that did not appear in the feces within $24 \mathrm{~h}$ were excluded from analysis. The sample with the least number of bags that appeared in the feces within 24 h had 17 bags. Thus, residue from 8 randomly selected bags was composited within sample to provide duplicate samples, used to determine postruminal and total tract STD and undegradable intake protein (UIP) digestibility. Two simulated masticate ground HMC and DRC samples from each hybrid were analyzed for particle size determination using the techniques described in Exp. 1. Initial corn samples and residues from both the ruminal and postruminal incuba- tions were analyzed for $\mathrm{N}$ and starch as described in Exp. 1.

Nutrient digestibility and particle size data were analyzed using the MIXED procedure of SAS. In situ bag was the experimental unit for DMD data, and composited in situ bags were the experimental unit for starch and protein digestibility. The model for nutrient digestibility consisted of processing method, hybrid, time, and all of the respective interactions. The model for particle size data consisted of processing method, hybrid, and the processing method $\times$ hybrid interaction. Least squares means were separated using the least significant difference method when a significant $F$-test $(P<0.05)$ was detected. The CORR procedure of SAS was used to test for correlation between variables of interest.

\section{RESULTS AND DISCUSSION}

\section{Experiment 1}

Nutrient Intake and Digestibility. There were no significant $(P$ $>0.10)$ hybrid $\times$ processing method interactions for nutrient intake. Dry matter, OM, and starch intake were similar $(P>0.15)$ among hybrids (Table 2). Nutrient intake was greater $(P<0.02)$ for steers consuming HMC compared with DRC. In the review by Owens et al. (1997), DMI was generally $6 \%$ lower for animals consuming HMC compared with DRC. If acidosis resulting from the rapid fermentation of HMC in the rumen causes animals to consume less DM, the intakes may also be lower for HMC diets (Fulton et al., 1979). However, Stock et al. (1987, 1991) observed numerically higher intakes for animals consuming HMC compared with DRC. The inclusion of by-products such as wet corn gluten feed (WCGF) has been shown to reduce the incidence of subacute acidosis in feedlot cattle (Krehbiel et al., 1995). In both the feedlot performance study (Jaeger et al., 2006) and the current metabolism study, WCGF was included in all diets to mediate acidosis. If one hybrid had a very rapid degradation rate compared with the others, cattle performance may have been negatively affected, and animals consuming the hybrid with the greatest starch availability may have had the poorest performance (Owens et al., 1998).

Total tract nutrient digestibilities were affected by both hybrid and processing method (Table 2), and the hybrid $\times$ processing method interaction was not significant $(P>0.28)$. Dry matter digestibility was greater for hybrid $1(P=0.03)$ than for hybrid 2, and tended $(P=0.08)$ to be greater than hybrid 3 . Organic matter digestibility was greater $(P<0.01)$ for hybrid 1 than hybrid 2. Additionally, OM digestibility for hybrid 3 tended $(P=0.06)$ to be greater compared with hybrid 2 . Starch digestibility was greater $(P=0.02)$ for hybrid 1 $(96.5 \%)$ compared with hybrids 2 and 3 (95.6 and $95.5 \%$, respectively). It is interesting to note that when these hybrids were fed as DRC, starch digestibilities did not differ for hybrids 2 and 3 and the hybrid by processing method interaction was not significant $(P=0.80)$. Although G:F was not statistically different in a feedlot performance study for these 2 hybrids fed as DRC (Jaeger et al., 2006), cattle consuming hybrid 2 were approximately $3.5 \%$ more efficient compared with those consuming hybrid 3 . It was hypothesized, based on the performance data and kernel traits, that digestibility would be greatest for hybrid 1 , followed by hybrids 2 and 3 . The results in the current study agree with ruminal in situ DMD data from Jaeger et al. (2006) and Exp. 2. In these studies, in situ ruminal DMD was numerically greater for hybrid 3 compared with hybrid 2 .

As expected, total tract nutrient digestibilities tended to be greater for HMC compared with DRC. Dry matter digestibility tended $(P=0.10)$ to be greater for HMC compared with DRC (72.6 and 68.0\%, respectively). Organic matter and STD were greater ( $P=0.05$ and $P=0.02$, respectively) for HMC compared with DRC. These results are in agreement with those found in the reviews of Owens et al. (1986), Theurer (1986), and Hunting- 
Table 2. Effect of corn hybrid and processing method on DM, OM, and starch intake and digestibility in Exp. 1

\begin{tabular}{|c|c|c|c|c|c|c|c|c|c|c|}
\hline \multirow[b]{3}{*}{ Item } & \multicolumn{6}{|c|}{ Dietary treatment ${ }^{1}$} & \multirow[b]{3}{*}{ SEM $^{2}$} & \multirow{2}{*}{\multicolumn{3}{|c|}{$P$-value ${ }^{3}$}} \\
\hline & \multicolumn{3}{|c|}{ DRC } & \multicolumn{3}{|c|}{ HMC } & & & & \\
\hline & 1 & 2 & 3 & 1 & 2 & 3 & & Process & Hybrid & $\mathbf{P} \times \mathrm{H}$ \\
\hline \multicolumn{11}{|l|}{ DM } \\
\hline Intake, kg & 9.4 & 10.3 & 10.0 & 10.6 & 10.7 & 10.5 & 0.6 & $<0.01$ & 0.19 & 0.28 \\
\hline Digestibility, \% & 79.8 & 74.1 & 76.5 & 80.5 & 77.7 & 78.3 & 2.1 & 0.10 & 0.03 & 0.63 \\
\hline \multicolumn{11}{|l|}{$\mathrm{OM}$} \\
\hline Intake, kg & 7.6 & 8.7 & 8.2 & 9.2 & 9.0 & 8.7 & 0.7 & 0.02 & 0.45 & 0.18 \\
\hline Digestibility, \% & 79.9 & 74.4 & 76.3 & 82.5 & 78.4 & 79.0 & 2.5 & 0.05 & 0.04 & 0.91 \\
\hline \multicolumn{11}{|l|}{ Starch } \\
\hline Intake, kg & 4.2 & 4.4 & 4.2 & 4.9 & 4.8 & 4.7 & 0.3 & $<0.01$ & 0.68 & 0.67 \\
\hline Digestibility, \% & 96.1 & 95.1 & 95.3 & 97.0 & 96.0 & 95.8 & 0.5 & 0.02 & 0.02 & 0.80 \\
\hline
\end{tabular}

${ }^{1}$ Hybrids consisted of Golden Harvest H-8562 (1), Pioneer 33P67 (2), and Golden Harvest H-9230Bt (3); processed as dry-rolled corn (DRC) or high-moisture corn (HMC).

${ }^{2}$ SEM for the hybrid $\times$ processing method interaction.

${ }^{3}$ Process $=$ main effects of dry-rolling vs. high-moisture ensiling; hybrid = main effect of hybrid; $\mathrm{P} \times \mathrm{H}=$ interaction of processing method and hybrid.

ton (1997), in which total tract nutrient digestibility was greater for HMC compared with DRC.

Similar studies conducted to evaluate the effects of processing method on hybrids varying in kernel traits have observed a hybrid $\times$ processing method interaction for feedlot performance and digestibility. The flint corn genotype is often associated with a more vitreous endosperm and lower ruminal STD (Philippeau et al., 1998, 1999a). A feedlot performance study conducted by Macken et al. (2003) evaluated the effects of starch endosperm type (dent vs. flint) and corn processing method (HMC vs. DRC). When these hybrids were fed as DRC, cattle consuming the hybrid with the floury endosperm were $5.9 \%$ more efficient than those consuming the flinty endosperm. When these same hybrids were fed as HMC, no differences were observed between hybrids. Owens and Zinn (2005) reported a hybrid $\times$ processing method interaction when 10 hybrids processed as DRC, HMC, or steam-flaked corn (SFC) were fed. When fed as DRC, the hybrid with the least amount of fecal starch (and lowest ratio of hard endosperm) did not have the lowest fecal starch when fed as SFC or HMC. Similarly,
Corona et al. (2006) observed lower total tract STD for hybrids as kernel vitreousness increased when processed as DRC, and they observed no differences when processed as SFC. Results from these studies suggest that the increase in STD among hybrids with less desirable physical properties is greater when a more intense grain processing method is used. In contrast to the findings of these studies, hybrid 1 in the current study appeared to maintain a nutrient digestibility advantage over hybrids 2 and 3 , regardless of the processing method used. These results may be due to the larger, softer kernel traits of this hybrid. One explanation for the absence of a hybrid $\times$ processing method interaction in this study may be a result of the moisture content of the HMC (28\%). Benton et al. (2005a) reported that gain efficiency for steers consuming early harvested HMC at $30 \%$ moisture was greater compared with HMC at $24 \%$ moisture. Similarly, the authors observed an efficiency response for reconstituted HMC fed at $35 \%$ compared with $28 \%$ moisture. When moisture or length of ensiling are increased for early harvested HMC or reconstituted HMC, ruminal DIP and DMD are increased (Benton et al., 2005b). Results from the studies conducted by Benton et al. (2005a, 2005 b) suggest that if the DRC were reconstituted to a moisture greater than $28 \%$, the vitreousness properties of hybrids 2 and 3 might be negated, allowing for similar digestibility as hybrid 1.

Ruminal $\boldsymbol{V F A}$. A hybrid $\times$ processing method interaction $(P<0.01)$ existed for molar proportions $(\%)$ of propionate, butyrate concentration, and acetate-to-propionate $(\mathbf{A}: \mathbf{P})$ ratio (Table 3 ). The increase in molar percentage of propionate for hybrid 3 when processed as HMC compared with DRC was 15.9 percentage units, whereas the increase for hybrids 1 and 2 was less, at 10.0 and 6.2 percentage units, respectively. The larger increase in the molar percentage of propionate suggests that the harder kernel traits for hybrid 3 may have limited rumen degradation when fed as DRC. These data are similar to the VFA measurements taken in a previous study (Jaeger et al., 2006) in which propionate concentrations were lower for hybrid 3 compared with 6 other hybrids fed as DRC. These kernel traits were altered through high-moisture ensiling, possibly allowing more starch from hybrid 3 to be digested in 
Table 3. Effect of corn hybrid and processing method on VFA concentration and ruminal pH in Exp. 1

Dietary treatment ${ }^{1}$

\begin{tabular}{|c|c|c|c|c|c|c|c|c|c|c|}
\hline \multirow[b]{3}{*}{ Item } & & \multirow[b]{3}{*}{$\mathrm{SEM}^{2}$} & \multirow{2}{*}{\multicolumn{3}{|c|}{$P$-value ${ }^{3}$}} \\
\hline & \multicolumn{3}{|c|}{ DRC } & \multicolumn{3}{|c|}{ HMC } & & & & \\
\hline & 1 & 2 & 3 & 1 & 2 & 3 & & Process & Hybrid & $\mathrm{P} \times \mathrm{H}$ \\
\hline \multicolumn{11}{|l|}{ VFA } \\
\hline \multirow{2}{*}{$\begin{array}{l}\text { Acetate, } \mathrm{mM} \\
\mathrm{mol} / 100 \mathrm{~mol}\end{array}$} & 50.6 & 52.9 & 52.0 & 49.8 & 49.1 & 48.1 & 2.1 & 0.02 & 0.79 & 0.47 \\
\hline & 48.5 & 48.6 & 50.2 & 44.2 & 46.5 & 45.5 & 1.4 & $<0.01$ & 0.25 & 0.33 \\
\hline \multirow{2}{*}{$\begin{array}{l}\text { Propionate, } \mathrm{mM} \\
\mathrm{mol} / 100 \mathrm{~mol}\end{array}$} & 38.0 & 36.1 & 30.1 & 48.0 & 41.9 & 46.4 & 3.2 & $<0.01$ & 0.07 & 0.06 \\
\hline & $36.2^{\mathrm{bc}}$ & $33.5^{\mathrm{c}}$ & $28.6^{d}$ & $46.2^{\mathrm{a}}$ & $39.7^{\mathrm{b}}$ & $44.5^{\mathrm{a}}$ & 2.4 & $<0.01$ & $<0.01$ & $<0.01$ \\
\hline Butyrate, mM & $9.2^{\mathrm{ab}}$ & $12.8^{\mathrm{cd}}$ & $15.8^{\mathrm{d}}$ & $7.4^{\mathrm{ab}}$ & $10.2^{\mathrm{bc}}$ & $6.7^{\mathrm{a}}$ & 1.8 & $<0.01$ & 0.02 & $<0.01$ \\
\hline Total VFA, mM & 104.8 & 108.8 & 105.5 & 104.4 & 110.5 & 106.0 & 3.9 & 0.69 & 0.57 & 0.23 \\
\hline$A: P^{4}$ & $1.41^{\mathrm{c}}$ & $1.45^{c}$ & $2.06^{d}$ & $0.86^{a}$ & $1.20^{\mathrm{bc}}$ & $1.08^{\mathrm{b}}$ & 0.14 & $<0.01$ & $<0.01$ & $<0.01$ \\
\hline \multicolumn{11}{|l|}{ Ruminal pH } \\
\hline Average $\mathrm{pH}$ & 5.58 & 5.59 & 5.78 & 5.65 & 5.66 & 5.53 & 0.09 & 0.58 & 0.91 & 0.10 \\
\hline Maximum pH & 6.24 & 6.20 & 6.36 & 6.49 & 6.32 & 6.25 & 0.11 & 0.24 & 0.53 & 0.15 \\
\hline Minimum pH & 5.13 & 5.13 & 5.31 & 5.03 & 5.15 & 4.89 & 0.11 & 0.08 & 0.83 & 0.15 \\
\hline pH variance ${ }^{5}$ & 0.048 & 0.044 & 0.043 & 0.098 & 0.068 & 0.082 & 0.001 & $<0.01$ & 0.38 & 0.62 \\
\hline Time $<5.6^{6}$ & 763 & 744 & 518 & 698 & 651 & 834 & 146 & 0.60 & 0.90 & 0.19 \\
\hline Area $<5.6^{7}$ & 215 & 164 & 101 & 197 & 169 & 295 & 67 & 0.25 & 0.80 & 0.20 \\
\hline
\end{tabular}

a-d Within a row, means with different superscripts differ $(P<0.05)$.

${ }^{1}$ Hybrids consisted of Golden Harvest H-8562 (1), Pioneer 33P67 (2), and Golden Harvest H-9230Bt (3); processed as dry-rolled corn (DRC) or high-moisture corn (HMC).

${ }^{2} \mathrm{SEM}$ for the hybrid $\times$ processing method interaction.

${ }^{3}$ Process $=$ main effects of dry-rolling vs. high-moisture ensiling; hybrid = main effect of hybrid; $\mathrm{P} \times \mathrm{H}=$ interaction of processing method and hybrid.

${ }^{4}$ Acetate:propionate $(A: P)$ ratio calculated using millimolar concentrations.

${ }^{5}$ Varance of daily ruminal $\mathrm{pH}$.

${ }^{6}$ Time $<5.6=$ minutes that ruminal $\mathrm{pH}$ was below 5.6.

${ }^{7}$ Area $<5.6=$ ruminal $\mathrm{pH}$ units below 5.6 by minute.

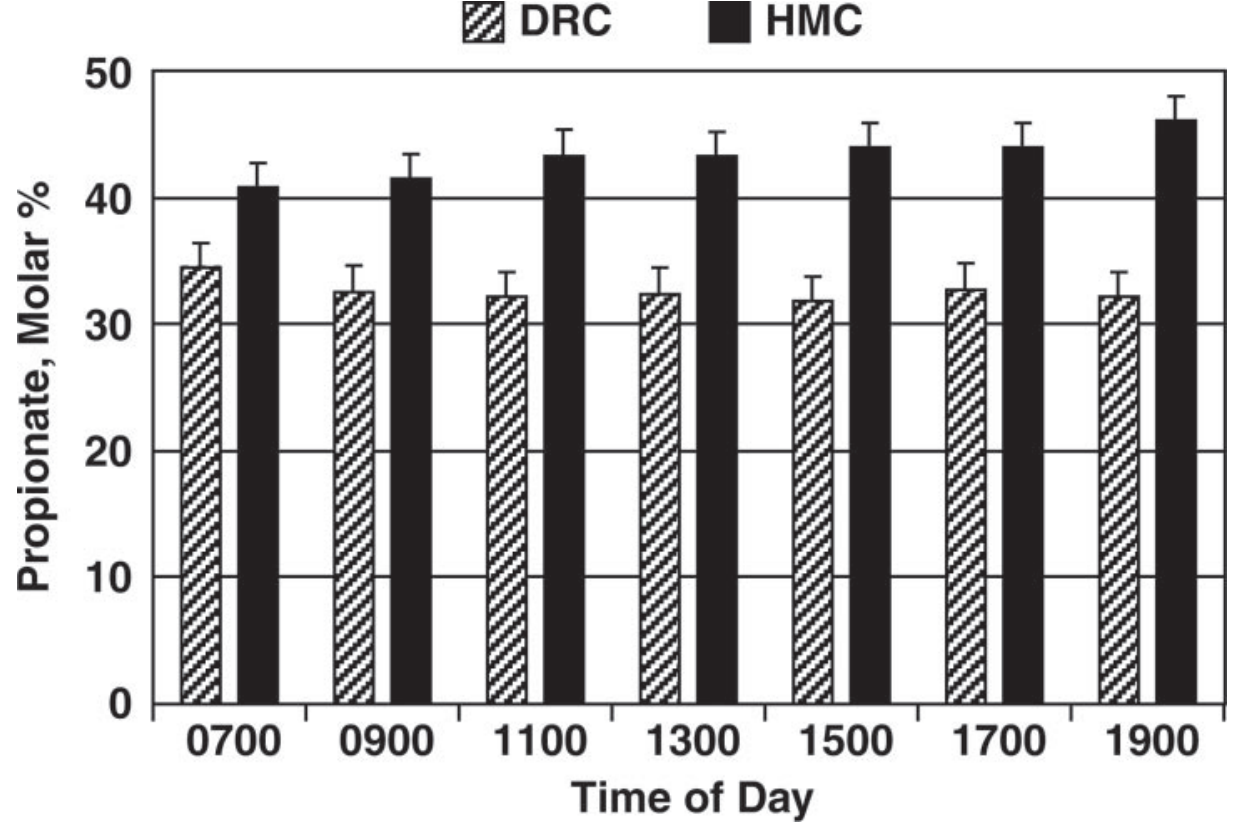

Figure 1. Processing method $\times$ time interaction for molar proportion of propionate $(P$ $<0.01)$. Animals were fed dry-rolled corn (DRC) or high-moisture corn (HMC) once daily at $0730 \mathrm{~h}$. Vertical bars represent the SEM. the rumen, which resulted in a greater increase in propionate concentrations. In contrast to the STD data, hybrid 1 did not maintain an advantage over hybrid 3 for the molar percentage of propionate when both were fed as $\mathrm{HMC}$. The reduction in the $\mathrm{A}: \mathrm{P}$ ratio when these hybrids were processed as HMC compared with DRC was similar to the increase for the propionate molar proportions. The decrease in the A:P ratio from $\mathrm{DRC}$ to $\mathrm{HMC}$ for hybrids 1 and 3 (0.55 and 0.98 units, respectively) was greater compared with the decrease for hybrid $2(0.25$ units). The smaller decrease in the A:P ratio for hybrid 2 is due to the smaller magnitude of change found for the concentration of propionate when fed as HMC compared with DRC. Ruminal butyrate concentration was greatest $(P<0.01)$ for hybrid 3 as 
Table 4. Effect of corn hybrid and processing method on intake patterns in Exp. 1

\begin{tabular}{|c|c|c|c|c|c|c|c|c|c|c|}
\hline \multirow[b]{3}{*}{ Item } & \multicolumn{6}{|c|}{ Dietary treatment ${ }^{1}$} & \multirow[b]{3}{*}{ SEM $^{2}$} & \multirow{2}{*}{\multicolumn{3}{|c|}{$P$-value ${ }^{3}$}} \\
\hline & \multicolumn{3}{|c|}{ DRC } & \multicolumn{3}{|c|}{ HMC } & & & & \\
\hline & 1 & 2 & 3 & 1 & 2 & 3 & & Process & Hybrid & $\mathbf{P} \times \mathbf{H}$ \\
\hline \multicolumn{11}{|l|}{ Intake } \\
\hline DMI, kg & 9.4 & 10.3 & 10.1 & 10.6 & 10.7 & 10.5 & 0.6 & $<0.01$ & 0.19 & 0.28 \\
\hline Rate, $\% / h$ & 12.7 & 13.5 & 15.1 & 17.4 & 15.2 & 17.4 & 1.6 & 0.04 & 0.51 & 0.63 \\
\hline \multicolumn{11}{|l|}{ Meals } \\
\hline Number/d & 7.5 & 6.2 & 7.0 & 7.6 & 7.2 & 7.4 & 0.8 & 0.12 & 0.15 & 0.50 \\
\hline Average size, kg & 1.5 & 1.9 & 1.6 & 1.6 & 1.7 & 1.5 & 0.2 & 0.65 & 0.21 & 0.60 \\
\hline \multicolumn{11}{|l|}{ Time spent eating } \\
\hline Total, $\mathrm{min} / \mathrm{d}$ & 566 & 533 & 558 & 613 & 631 & 647 & 52 & $<0.01$ & 0.72 & 0.58 \\
\hline Average meal, min & 83 & 95 & 86 & 88 & 92 & 96 & 8 & 0.56 & 0.06 & 0.69 \\
\hline
\end{tabular}

${ }^{1}$ Hybrids consisted of Golden Harvest H-8562 (1), Pioneer 33P67 (2), and Golden Harvest H-9230Bt (3); processed as dry-rolled corn (DRC) or high-moisture corn (HMC).

${ }^{2}$ Process $=$ main effects of dry-rolling vs. high-moisture ensiling; hybrid = main effect of hybrid; $\mathrm{P} \times \mathrm{H}=$ interaction of processing method and hybrid.

${ }^{3} \mathrm{SEM}$ for the hybrid $\times$ processing method interaction.

DRC but was lowest when processed as HMC.

A processing method $\times$ time interaction $(P<0.01)$ existed for molar percentage of propionate and the A:P ratio. Molar proportions of propionate for animals consuming DRC averaged $32.8 \%$ and remained close to this value throughout the sampling day (Figure 1). The molar percentage of propionate for animals consuming HMC was $34.6 \%$ before feeding and increased throughout the sampling day to $46.3 \% 12 \mathrm{~h}$ after feeding $(P$ $<0.01)$. There were no $(P>0.10)$ hybrid $\times$ time or processing method $\times$ time interactions for ruminal concentrations ( $\mathrm{m} M$ ) of VFA. Ruminal concentrations of acetate, propionate, butyrate, and total VFA were lowest before feeding and generally increased throughout the 12-h sampling day (data not shown).

Intake Patterns. Total time spent eating and intake rate (Table 4) were greater $(P<0.05)$ for animals consuming HMC compared with DRC. Total time spent eating was almost $16 \%$ longer for animals consuming HMC compared with those consuming DRC (630 and $552 \mathrm{~min}$, respectively). Intake rate was greater $(P<0.05)$ for animals consuming HMC $(16.7 \% / \mathrm{h})$ compared with animals consuming DRC $(13.8 \% / h)$. Average meal size was not different $(P=0.65)$ among processing methods and averaged $1.8 \mathrm{~kg} /$ meal. The number of meals consumed daily tended $(P=0.12)$ to be more for steers consuming HMC compared with DRC.

Ruminal $\boldsymbol{p H}$. There was a tendency $(P=0.10)$ for a hybrid $\times$ processing method interaction for average ruminal $\mathrm{pH}$ (Table 3). Steers consuming hybrids 1 and 2 as HMC had a numerically higher average $\mathrm{pH}$ compared with those fed the same hybrid as DRC. Conversely, average $\mathrm{pH}$ for steers consuming hybrid $3 \mathrm{had}$ a lower ruminal $\mathrm{pH}$ when fed as HMC compared with DRC. For the main effect of processing method, average $\mathrm{pH}$ was similar $(P=0.58)$ for HMC and DRC (5.61 and 5.65, respectively). The change in $\mathrm{pH}$ (maximum to minimum) was approximately $23 \%$ greater $(P<0.01)$ for steers consuming HMC compared with DRC (1.33 and 1.08 units, respectively). Similarly, $\mathrm{pH}$ variance was $33 \%$ greater $(P<0.01)$ for steers consuming HMC compared with DRC. There was also a tendency $(P=0.08)$ for minimum $\mathrm{pH}$ to be lower for steers consuming HMC compared with DRC (5.02 and 5.19, respectively). Time and area below 5.6 was not influenced by processing method or hybrid $(P>0.10)$. Macken et al. (2003) found similar results for $\mathrm{pH}$ change and $\mathrm{pH}$ variance when DRC and HMC diets were fed. Ruminal fermentation characteristics such as these may indicate that a more intense processing method produces a more rapid starch fermentation rate compared with DRC.

One explanation for average $\mathrm{pH}$ to be similar for animals consuming HMC and DRC may be due to more total time spent eating and a tendency $(P=0.12)$ for steers consuming HMC to eat more meals per day. The intake behavior may be due to the animal regulating intake to minimize the incidence of ruminal acidosis. Consuming a smaller quantity of feed more frequently and allowing ruminal $\mathrm{pH}$ to recover between meals may contribute to a similar average $\mathrm{pH}$ for both processing methods. Even though the addition of WCGF to these diets may have mediated ruminal $\mathrm{pH}$ (Krehbiel et al., 1995), there is enough fermentable starch in the DRC diets for animals to experience ruminal acidosis, which is supported by the VFA data. Animals consuming DRC diets also regulate intake 
Table 5. Effect of corn grain hybrid and processing method on particle size in Exp. 1 and 2

\begin{tabular}{|c|c|c|c|c|c|c|c|c|c|c|}
\hline \multirow[b]{3}{*}{ Item } & \multicolumn{6}{|c|}{ Dietary treatment ${ }^{1}$} & \multirow[b]{3}{*}{ SEM $^{2}$} & \multirow{2}{*}{\multicolumn{3}{|c|}{$P$-value ${ }^{3}$}} \\
\hline & \multicolumn{3}{|c|}{ DRC } & \multicolumn{3}{|c|}{ HMC } & & & & \\
\hline & 1 & 2 & 3 & 1 & 2 & 3 & & Process & Hybrid & $\mathbf{P} \times \mathbf{H}$ \\
\hline \multicolumn{11}{|l|}{ Exp. $1^{4}$} \\
\hline $\mathrm{GMD},{ }^{5} \mu \mathrm{m}$ & 4,648 & 4,724 & 3,651 & 4,780 & 3,611 & 2,918 & 358 & 0.03 & $<0.01$ & 0.11 \\
\hline $\mathrm{GSD},{ }^{6} \mu \mathrm{m}$ & 1.70 & 1.62 & 2.41 & 2.25 & 3.32 & 3.99 & 0.37 & $<0.01$ & $<0.01$ & 0.13 \\
\hline Washout, ${ }^{7} \%$ & 1.21 & 1.10 & 4.27 & 3.55 & 8.75 & 12.24 & 1.64 & $<0.01$ & $<0.01$ & 0.09 \\
\hline \multicolumn{11}{|l|}{ Exp. $2^{8}$} \\
\hline GMD, $\mu \mathrm{m}$ & 2,184 & 2,648 & 1,747 & 1,131 & 1,380 & 1,039 & 143 & $<0.01$ & $<0.01$ & 0.08 \\
\hline $\mathrm{GSD}, \mu \mathrm{m}$ & 2.98 & 2.43 & 3.42 & 4.73 & 4.34 & 4.89 & 0.14 & $<0.01$ & $<0.01$ & 0.16 \\
\hline Washout, \% & 8.0 & 4.7 & 11.7 & 20.2 & 24.9 & 27.1 & 1.6 & $<0.01$ & $<0.01$ & 0.77 \\
\hline
\end{tabular}

${ }^{1}$ Hybrids consisted of Golden Harvest H-8562 (1), Pioneer 33P67 (2), and Golden Harvest H-9230Bt (3); processed as dry-rolled corn (DRC) or high-moisture corn (HMC).

${ }^{2} \mathrm{SEM}$ for the hybrid by processing method interaction.

${ }^{3}$ Process $=$ main effects of dry-rolling vs. high-moisture ensiling; hybrid $=$ main effect of hybrid; $\mathrm{P} \times \mathrm{H}=$ interaction of processing method and hybrid.

${ }^{4}$ Corn hybrids processed using a roller mill in Exp. 1.

${ }^{5} \mathrm{GMD}=$ geometric mean diameter.

${ }^{6} \mathrm{GSD}=$ geometric standard deviation .

${ }^{7}$ Proportion of sample not retained on screens.

${ }^{8}$ Corn hybrids processed using a simulated masticate grind Wiley mill (Thomas Scientific, Swedesboro, NJ; 0.625-cm screen).

similar to those consuming HMC, but they do not experience the variance in ruminal $\mathrm{pH}$ or the same magnitude of change.

Particle Size. The GMD, GSD, and proportion of sample not retained on a screen (percentage of washout) was influenced by both corn hybrid and processing method $(P<0.05$; Table 5). The GMD was approximately $28 \%$ lower $(P<0.01)$ for hybrid 3 compared with hybrids 1 and 2 . The percentage of washout for hybrid 3 was more than 3 times greater $(P<$ $0.01)$ compared with hybrids 1 and 2. Similarly, the GSD was greater $(P$ $<0.01$ ) for hybrid 3 compared with hybrids 1 and 2. The GMD for DRC was approximately $15 \%$ greater $(P=$ 0.03) compared with HMC. Both the GSD and percentage of washout were greater $(P<0.01)$ for HMC compared with DRC.

The results from particle size analysis of DRC in this study conflict with data from 3 studies conducted by Philippeau et al. (1998, 1999a,b) who observed a smaller particle size for dent corn compared with flint. These differences may be a result of the use of a roller mill in our study and the use of a hammer mill with a 3-mm screen for the studies conducted by Philippeau et al. (1998, 1999a,b). When kernels with hard physical properties are passed through the rollers on a roller mill, the kernels may be more brittle and break apart, yielding smaller particles compared with kernels with softer kernel traits. The smaller particle size for hybrid 3 may have masked the influence of the less desirable kernel traits with this hybrid on nutrient digestibility. Even though differences existed among hybrids for particle size, the total tract STD and ruminal propionate concentration were greater for hybrid 1 compared with hybrid 3 .

All corn samples were ground through the same roller mill to produce similar particle sizes for DRC and reconstituted HMC. The differences in particle size among processing methods may be due to the equipment used to pack the HMC into the plastic bags. The knives on the bagging equipment may have reduced the particle size of the corn as it was packed. Another explanation may be the large difference for the percentage of washout (3.7 times greater for HMC compared with DRC). The smaller particle size found for HMC may have contributed to the overall increase in total tract nutrient digestibility for HMC compared with DRC. Secrist et al. (1995) and Remond et al. (2004) observed that total tract STD increased linearly as particle size decreased. However, Galyean et al. (1981) observed greater in situ starch and DM digestibilities for HMC compared with DRC at 3,000, 1,500, and $750 \mu \mathrm{m}$. Additionally, Galyean et al. (1981) found that ruminal starch and DM digestibilities for HMC at larger particle sizes $(3,000 \mu \mathrm{m})$ were greater compared with DRC at a smaller particle size $(1,500 \mu \mathrm{m})$. These results imply that nutrient digestibility among processing methods in the current experiment was not due solely to particle size. Previous research has 
shown that fermentation of corn during the ensiling process disrupts the protein matrix surrounding the starch granules, leading to an improved digestibility of the grain (Prigge et al., 1976; Britton and Krause, 1985).

\section{Experiment 2}

Particle Size. Particle size analysis of the corn grain indicated there were differences among hybrids and processing methods for the GMD and the GSD. There was a tendency $(P=0.08)$ for a hybrid $\times$ processing method interaction for GMD (Table

$5)$. The GMD was largest $(P<0.01)$ for hybrid 2 , intermediate for hybrid 1 , and smallest for hybrid 3 when processed as DRC. However, when processed as HMC, no significant differences existed. There was no attempt to change the particle size among hybrids or processing methods by altering the knives on the Wiley mill.

The GMD was larger $(P<0.01)$ for DRC compared with HMC $(2,193$ and $1,183 \mu \mathrm{m}$, respectively) when ground with the simulated masticate grind. The GMD for hybrid $2(2,014 \mu \mathrm{m})$ was $21 \%$ greater $(P=0.07)$ than for hybrid $1(1,658 \mu \mathrm{m})$, and was $44 \%$ greater $(P<0.01)$ than for hybrid 3 $(1,393 \mu \mathrm{m})$. These data suggest the hybrids responded differently for the masticate grind compared with the rolling process. When these same hybrids were fed as DRC or rolled HMC in Exp. 1, hybrid 1 had a larger GMD $(4,714 \mu \mathrm{m})$ compared with hybrids 2 and $3(4,168$ and $3,284 \mu \mathrm{m}$, respectively). The GMD was consistently larger for hybrid 2, intermediate for hybrid 1 , and smallest for hybrid 3 when processed as rolled or simulated masticate DRC. When rolled HMC samples were analyzed for particle size, the GMD for hybrid 1 was larger than for hybrid 2. Conversely, when HMC samples were ground through the masticate grind, the GMD for hybrid 1 was smaller than for hybrid 2. The GMD for hybrid 3 was consistently smaller than for hybrids 1 and 2 , independent of processing method
(DRC vs. HMC) or grind method (simulated masticate vs. rolled).

Differences among processing methods for GMD are comparable to animal masticated samples, with HMC having a smaller GMD than DRC. Macken (2004) observed the GMD for DRC and rolled HMC samples to be 4,730 and 2,901 $\mu \mathrm{m}$, respectively. When these samples (Macken, 2004) were fed to animals, the GMD was reduced $45 \%$ for DRC and $72 \%$ for HMC $(2,593$ and $792 \mu \mathrm{m}$, respectively). The percentage reduction of simulated masticate ground samples from the original corn samples in the current study was $69 \%$ for HMC (3,769 and 1,184 $\mu \mathrm{m}$, respectively). The percentage reduction from the original HMC sample ground frozen through the simulated grind was comparable with the mechanical action caused by animal mastication. Additionally, the particle size reduction for DRC was comparable with what Macken (2004) observed for masticated DRC. The reduction for the GMD of the 3 DRC samples averaged $49 \%$, similar to the $45 \%$ reduction Macken (2004) observed for the GMD of DRC and masticated DRC (4,730 and 2,593 $\mu \mathrm{m}$, respectively).

There was an inverse relationship $(P<0.01, \mathrm{r}=-0.92)$ between the GMD and bag washout. As the GMD increased, the percentage of sample washed out of the nonincubated bags decreased. These results may be due to less surface area of the endosperm exposed for larger compared with smaller particles. Szasz et al. (2005) observed total tract STD for a flinty hybrid to be greater compared with a floury hybrid. Particle size analysis of the samples revealed that the flinty hybrid had a smaller GMD and 15.8\% larger surface area compared with the floury hybrid. The authors concluded that the difference in surface area may be responsible for the improved starch utilization of the flinty hybrid observed in that study. The harder kernel characteristics of hybrid 3 in the current study are more similar to the flinty hybrid compared with hybrids 1 and 2 .
DM Digestibility. Ruminal DMD was influenced by hybrid, incubation time, and processing method (Tables 6 to 8 ). Ruminal DMD for samples incubated for $30 \mathrm{~h}$ were $22 \%$ greater $(P<0.01)$ compared with samples incubated $20 \mathrm{~h}$ (62.1 and 50.8\%, respectively; data not presented). Ruminal DMD for HMC was $33 \%$ greater $(P<$ 0.01) compared with DRC (64.4 and $48.5 \%$, respectively). These results are lower than values reported in other studies that measured in situ ruminal DMD for DRC and HMC. Galyean et al. (1981) and Benton et al. (2005a) observed DM disappearance to be approximately 1.5 and 2.5 times greater, respectively, for HMC compared with DRC. Differences among trials for ruminal DMD may be due to incubation time, particle size, or other factors (Vanzant et al., 1998). Ruminal DMD for hybrids 1 and 3 (58.0 and 59.3\%, respectively) were greater $(P=0.01)$ than for hybrid $2(52.0 \%)$.

A hybrid $\times$ processing method $\times$ time interaction $(P<0.05)$ was found for postruminal DMD (Figure 2). Postruminal DMD was numerically greater for 4 of the samples incubated for $30 \mathrm{~h}$ compared with the 20-h incubation. A possible explanation for postruminal digestion being greater for samples incubated longer may be that less residue entered the duodenum because the samples were degraded more in the rumen. If this was true, HMC samples would also have had less residue entering the duodenum because of greater ruminal digestibility, resulting in greater postruminal DMD compared with DRC. However, hybrid 2 was the only hybrid that had a greater postruminal DMD for the 30-h incubation and a greater postruminal DMD for HMC compared with DRC. When hybrid 3 was processed as HMC, postruminal DMD for the 20-h incubation was $12 \%$ greater than for the 30 -h incubation. A smaller GMD for hybrid 3 processed as HMC would allow for greater ruminal degradation, leaving mostly indigestible material that is not degradable postruminally after a longer incubation time. Postruminal DMD for hybrid 1 processed as DRC 
Table 6. Effect of corn hybrid and processing method on nutrient digestibility and bag washout in Exp. $2^{1}$

\begin{tabular}{|c|c|c|c|c|c|c|c|c|c|c|}
\hline \multirow[b]{3}{*}{ Item } & \multicolumn{6}{|c|}{ Dietary treatment $^{2}$} & \multirow[b]{3}{*}{ SEM $^{3}$} & \multirow{2}{*}{\multicolumn{3}{|c|}{$P$-value ${ }^{4}$}} \\
\hline & \multicolumn{3}{|c|}{ DRC } & \multicolumn{3}{|c|}{ HMC } & & & & \\
\hline & 1 & 2 & 3 & 1 & 2 & 3 & & Process & Hybrid & $\mathrm{P} \times \mathrm{H}$ \\
\hline \multicolumn{11}{|l|}{ DM digestibility } \\
\hline Ruminal $^{5}$ & 51.3 & 44.2 & 49.8 & 64.7 & 59.8 & 68.7 & 4.9 & $<0.01$ & 0.01 & 0.54 \\
\hline Postruminal $^{5}$ & $76.3^{b c}$ & $71.9^{a}$ & $74.9^{b}$ & $74.8^{\mathrm{b}}$ & $77.9^{c}$ & $71.9^{a}$ & 1.1 & 0.49 & 0.02 & $<0.01$ \\
\hline Total tract 6 & $88.5^{c}$ & $84.3^{a}$ & $87.4^{b}$ & $91.0^{d}$ & $91.0^{d}$ & $91.4^{d}$ & 0.5 & $<0.01$ & $<0.01$ & $<0.01$ \\
\hline Bag washout $^{7}$ & 9.8 & 6.4 & 11.3 & 39.8 & 25.2 & 34.7 & 5.1 & $<0.01$ & $<0.01$ & 0.77 \\
\hline \multicolumn{11}{|l|}{ Starch digestibility } \\
\hline Ruminal $^{5}$ & 56.1 & 44.8 & 52.3 & 68.9 & 66.0 & 75.2 & 6.1 & $<0.01$ & 0.14 & 0.41 \\
\hline Postruminal ${ }^{6}$ & 93.6 & 91.0 & 93.1 & 97.0 & 93.7 & 96.1 & 2.6 & $<0.01$ & $<0.01$ & 0.99 \\
\hline Total tract ${ }^{5}$ & 97.1 & 95.1 & 96.7 & 99.0 & 97.7 & 99.0 & 0.3 & $<0.01$ & $<0.01$ & 0.52 \\
\hline \multicolumn{11}{|l|}{ Protein digestibility } \\
\hline $\mathrm{DIP}, 5 \% \mathrm{CP}$ & 57.0 & 49.14 & 56.5 & 72.8 & 68.0 & 74.6 & 4.9 & $<0.01$ & 0.12 & 0.90 \\
\hline UIP, \% CP & 43.0 & 50.9 & 43.5 & 27.2 & 32.0 & 25.4 & 4.9 & $<0.01$ & 0.12 & 0.90 \\
\hline Total tract ${ }^{5}$ & $90.5^{\mathrm{bc}}$ & $84.2^{\mathrm{a}}$ & $88.6^{b}$ & $94.0^{d}$ & $92.7^{\mathrm{cd}}$ & $94.2^{d}$ & 1.2 & $<0.01$ & $<0.01$ & 0.02 \\
\hline UIP digestibility ${ }^{6}$ & 78.2 & 69.0 & 73.8 & 80.1 & 76.7 & 76.5 & 3.0 & 0.03 & 0.02 & 0.35 \\
\hline
\end{tabular}

${ }^{a-d}$ Within a row, means with different superscripts differ $(P<0.05)$.

${ }^{1}$ Values presented in the table are the least squares means from the hybrid $\times$ processing method interaction.

${ }^{2}$ Hybrids consisted of Golden Harvest H-8562 (1), Pioneer 33P67 (2), and Golden Harvest H-9230Bt (3); processed as dry-rolled corn (DRC) or high-moisture corn (HMC).

${ }^{3} \mathrm{SEM}$ for the hybrid $\times$ processing method interaction.

${ }^{4}$ Process $=$ main effects of dry-rolling vs. high-moisture ensiling: hybrid = main effect of hybrid; $\mathrm{P} \times \mathrm{H}=$ interaction of processing method and hybrid.

${ }^{5}$ Ruminal and total tract digestibility expressed as percentage of nutrient inserted.

${ }^{6}$ Postruminal digestibility expressed as percentage entering the duodenum.

${ }^{7}$ Proportion of sample washed out of the in situ bag without incubation.

was similar for both the 20- and 30-h incubations. If the residue remaining after the 20-h incubation for this hybrid had a greater proportion of digestible material postruminally than after the 30-h incubation, the DM degraded postruminally expressed as a percentage entering may be as high as for the 30-h incubation, even though more total residue was inserted into the duodenum.

There were 3 significant 2-way interactions for total tract DMD: hybrid $\times$ processing method $(P<0.01)$, processing method $\times$ time $(P=0.02)$, and hybrid $\times$ time interactions $(P<$ 0.01). Total tract DMD among all 6 corn samples was found to be positively correlated $(P<0.01, \mathrm{r}=0.96)$ with ruminal DMD and negatively correlated $(P=0.01, \mathrm{r}=-0.93)$ with the GMD. These results are supported by the results of Secrist et al.
(1995), who observed a linear increase in STD when particle size decreased. When processed as DRC, total tract DMD for hybrid 1 was $1 \%$ greater $(P$ $<0.01)$ than for hybrid 3 , and $5 \%$ greater than for hybrid 2 (Table 6 ). However, when processed as HMC there were no differences among hybrids. These results may be due in part to the differences found for the GMD among hybrids when processed as DRC, and the lack of differences in GMD when processed as HMC. Trends in ruminal DMD were similar to total tract DMD, with digestibility being greatest for hybrid 1 , intermediate for hybrid 3, and lowest for hybrid 2 , but were not statistically different because of the smaller number of bags used for ruminal DMD $(\mathrm{n}=16)$ compared with total tract DMD ( $\mathrm{n}=$ 200).
Total tract DMD was greatest for HMC samples incubated for $30 \mathrm{~h}$ and least for DRC incubated for 20 h (Table 7). Digestibility of DRC samples incubated for $30 \mathrm{~h}$ were $1.4 \%$ greater $(P<0.01)$ compared with HMC samples incubated for $20 \mathrm{~h}$. This is a relatively small improvement in digestibility (1.4\%) compared with the additional time (50\% longer incubation) that DRC samples were incubated in the rumen. Total tract DMD among hybrids was greater $(P<0.01)$ for hybrids 1 and 3 (87.7 and 88.4\%, respectively) at the 20 -h incubation compared with hybrid 2 (85.8\%; Table $8)$. At the 30 -h incubation, DMD for hybrid $1(91.8 \%)$ was greater $(P<$ 0.01 ) than for either hybrids 2 or 3 (89.5 and $90.4 \%$, respectively).

Starch Digestibility. There were no statistical differences $(P=0.14)$ among hybrids for ruminal STD 


\section{Table 7. Processing method $\times$ ruminal incubation time interaction for DM digestibility in Exp. 2}

\begin{tabular}{|c|c|c|c|c|c|c|}
\hline \multirow[b]{3}{*}{ Item } & \multicolumn{4}{|c|}{ Incubation time ${ }^{1}$} & \multirow[b]{3}{*}{ SEM $^{2}$} & \multirow[b]{3}{*}{$P$-value } \\
\hline & \multicolumn{2}{|c|}{$20 \mathrm{~h}$} & \multicolumn{2}{|c|}{$30 \mathrm{~h}$} & & \\
\hline & DRC & HMC & DRC & HMC & & \\
\hline Postruminal $^{3}$ & $73.4^{\mathrm{a}}$ & $75.3^{b}$ & $75.3^{b}$ & $74.3^{\mathrm{a}}$ & 0.9 & $<0.01$ \\
\hline Total tract & $84.7^{\mathrm{a}}$ & $88.7^{b}$ & $89.9^{c}$ & $92.4^{\mathrm{d}}$ & 0.4 & 0.02 \\
\hline
\end{tabular}

${ }^{a-d}$ Within a row, means with different superscripts differ $(P<0.05)$.

${ }^{1}$ Ruminally incubated at 20 or $30 \mathrm{~h}$; processed as dry-rolled corn (DRC) or highmoisture corn (HMC).

${ }^{2} \mathrm{SEM}$ for the processing method $\mathrm{x}$ incubation time interaction.

${ }^{3}$ Postruminal digestibility expressed as percentage entering the duodenum.

(Table 6). However, ruminal STD was numerically greater for hybrids 1 and 3 (62.5 and $63.8 \%$, respectively) compared with hybrid $2(55.4 \%)$. These numerical differences may be due to the GMD found among hybrids. Ruminal STD was found to be negatively correlated $(P<0.01, \mathrm{r}=-0.93)$ with the GMD, similar to results of Philippeau et al. (1998, 1999a) who found that corn samples with a higher proportion of coarse particles had lower ruminal in situ STD. The main effects of time on ruminal STD indicated that samples incubated for
30 h had $24 \%$ greater STD $(P<0.01)$ compared with samples incubated for $20 \mathrm{~h}$ (67.1 and 54.1\%, respectively).

Ruminal STD was $37 \%$ greater $(P<0.01)$ for HMC compared with DRC samples (70.1 and 51.1\%, respectively). This difference is in agreement with the improvement in ruminal STD found by Cooper et al. (2002) for samples processed as HMC compared with DRC (31\%). Ruminal STD for HMC and DRC samples from Cooper et al. (2002) were lower (68.4 and $52.0 \%$, respectively) compared with the 30 -h incubation used
$\mathbb{Z} 20 \mathrm{~h} \square 30 \mathrm{~h}$

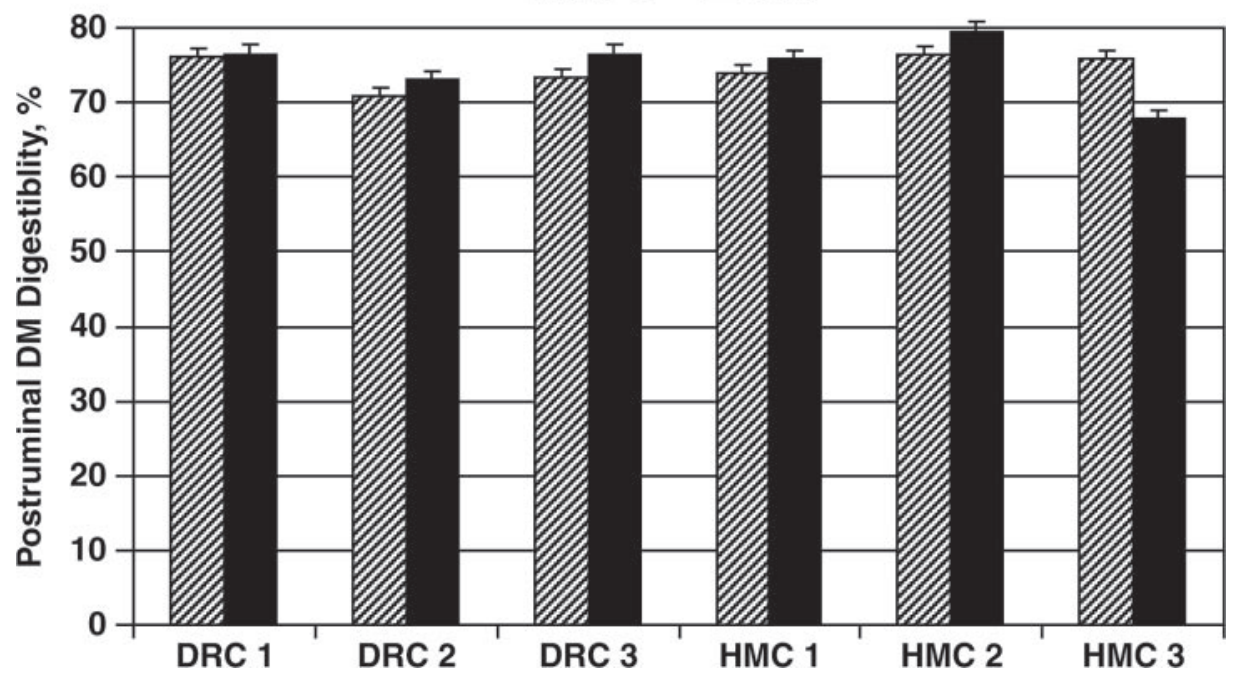

Figure 2. Hybrid $\times$ processing method $\times$ ruminal incubation time interaction $(P<$ 0.05 ) for postruminal DM digestibility expressed as percentage entering the duodenum for Exp. 2. Hybrids consisted of Golden Harvest H-8562 (1), Pioneer 33P67 (2), and Golden Harvest H-9230Bt (3); processed as dry-rolled corn (DRC) or high-moisture corn (HMC) ruminally incubated for 20 or $30 \mathrm{~h}$. in the current study $(76.5$ and $57.7 \%$, respectively). Samples in the current study were ground through a $0.625-$ $\mathrm{cm}$ screen, whereas the samples used by Cooper et al. (2002) were incubated similarly to what would be fed at the bunk (i.e., just processed as either DRC or HMC). Samples with particle sizes similar to masticated corn are more degradable in the rumen compared with the original processed corn (Simon, 2001; Macken, 2004).

Postruminal STD was approximately $3 \%$ greater for HMC compared with DRC samples (95.6 and 92.5\%, respectively). Postruminal digestibility of DRC averaged 68.9 and $68.4 \%$ in the reviews of Huntington (1997) and Owens and Zinn (2005), respectively. Postruminal STD for HMC was found to be 67.8 and $90.4 \%$ in the reviews of Huntington (1997) and Owens and Zinn (2005), respectively. The values for postruminal STD in this study may be greater because of fermentation of starch or protein in the hindgut (Voigt et al., 1985). However, the relative differences for postruminal STD in this study were similar to values in the review of Owens and Zinn (2005), with postruminal STD being greater for HMC compared with DRC.

Postruminal STD was greater $(P<$ 0.01 ) for hybrids 1 and 3 (95.3 and $94.6 \%$, respectively) compared with hybrid $2(92.3 \%)$. Total tract STD was also greater for hybrids 1 and 3 (98.1 and $97.8 \%$, respectively) compared with hybrid $2(96.4 \%)$. Because starch is more digestible than the total residue entering the duodenum for postruminal DMD, postruminal STD (expressed as a percentage entering the duodenum) was greater for samples that were digested more in the rumen. The main effect of time on postruminal STD was not as large as that of ruminal STD. However, differences did exist $(P=0.02)$ among samples that were incubated for $30 \mathrm{~h}$ compared with 20 h (94.7 and $93.5 \%$, respectively).

Protein Digestibility. A hybrid $\times$ processing method interaction $(P=$ 0.02) existed for total tract $\mathrm{CP}$ digestibility. Total tract CP digestibility 


\section{Table 8. Hybrid $\times$ ruminal incubation time interaction for DM digestibility in Exp. 2}

\begin{tabular}{|c|c|c|c|c|c|c|c|c|}
\hline \multirow[b]{3}{*}{ Item } & \multicolumn{6}{|c|}{ Incubation time $^{1}$} & \multirow[b]{3}{*}{ SEM $^{2}$} & \multirow[b]{3}{*}{$P$-value } \\
\hline & \multicolumn{3}{|c|}{$20 \mathrm{~h}$} & \multicolumn{3}{|c|}{$30 \mathrm{~h}$} & & \\
\hline & 1 & 2 & 3 & 1 & 2 & 3 & & \\
\hline Postruminal $^{3}$ & $75.0^{\mathrm{bc}}$ & $73.5^{\mathrm{ab}}$ & $74.6^{\mathrm{bc}}$ & $76.1^{c}$ & $76.3^{c}$ & $72.1^{d}$ & 1.1 & 0.02 \\
\hline Total tract & $87.7^{b}$ & $85.8^{a}$ & $88.4^{b}$ & $91.8^{d}$ & $89.5^{c}$ & $90.4^{\mathrm{c}}$ & 0.5 & $<0.01$ \\
\hline
\end{tabular}

${ }^{a-d}$ Within a row, means with different superscripts differ $(P<0.05)$.

${ }^{1}$ Ruminally incubated at 20 or 30 h; hybrids consisted of Golden Harvest H-8562 (1), Pioneer 33P67 (2), and Golden Harvest H-9230Bt (3).

${ }^{2} \mathrm{SEM}$ for the hybrid $\times$ incubation time interaction.

${ }^{3}$ Postruminal digestibility expressed as percentage entering the duodenum.

was greater for hybrids 1 and 3 (90.5 and $88.6 \%$, respectively) compared with hybrid $2(84.2 \%)$ when processed as DRC. Crude protein digestibility for hybrid 1 processed as DRC was similar to hybrid 2 processed as HMC (92.7\%). Total tract CP digestibility was $6.6 \%$ greater for HMC compared with DRC samples (93.6 and 87.8\%, respectively). Total tract $\mathrm{CP}$ digestibility was greater $(P<0.01)$ for samples incubated for $30 \mathrm{~h}$ compared with those incubated $20 \mathrm{~h} \mathrm{(92.4} \mathrm{and}$ $89.1 \%$, respectively).

Degradable intake protein (\% of $\mathrm{CP})$ tended $(P=0.12)$ to be greater for hybrids 1 and 3 (64.9 and 65.6\%, respectively) compared with hybrid $2(58.6 \%)$. Degradable intake protein was $32 \%$ greater for HMC samples compared with DRC (71.8 and $54.2 \%$, respectively). Samples incubated for $30 \mathrm{~h}$ had $17.6 \%$ greater DIP compared with those incubated for $20 \mathrm{~h}(68.0$ and $57.8 \%$, respectively; data not shown). The DIP content for DRC incubated for $20 \mathrm{~h}$ (48.0\%) in this study was greater than what Benton et al. (2005a) reported $(34.3 \%)$ when using an incubation time of $22 \mathrm{~h}$. Similarly, results from the $30-\mathrm{h}$ incubation of DRC in this study $(60.4 \%)$ were greater than those of the 29-h incubation $(31.1 \%)$ conducted by Cooper et al. (2002), who suggested that samples not ground to produce a smaller particle size would lower the DIP value by approximately 8 percentage units. However, Benton et al. (2005a) used the same masticate grind as in the current study to produce a sample with a smaller particle size and also found lower DIP values for DRC. Degradable intake protein for HMC samples incubated for 20 $\mathrm{h}(67.8 \%)$ in this study were similar to what Benton et al. (2005a) found for HMC at similar moisture levels (65.9\%). Ruminal STD and DIP were correlated for both the 20- and 30-h incubation times $(\mathrm{r}=0.97$ and 0.98 , respectively). This observation may be due to a disruption of the protein matrix surrounding the starch granules, leading to a greater amount of starch digested (Rooney and Pflugfelder, 1986).

Undegradable intake protein digestibility was $5.4 \%$ greater $(P=0.03)$ for HMC compared with DRC (77.7 and $73.7 \%$, respectively). Digestible UIP among hybrids was numerically greatest for hybrid 1 (79.1\%), intermediate for hybrid $3(75.2 \%)$, and lowest for hybrid $2(72.9 \%)$. The UIP digestibility for samples incubated at $30 \mathrm{~h}$ was not different $(P=0.24)$ from those incubated for $20 \mathrm{~h}(76.8$ and $74.7 \%$, respectively). These results conflict with work conducted by Beckers et al. (1996), who found that a shorter ruminal incubation time led to an increase in UIP digestibility. These differences may be due to the type of samples used by Beckers et al. (1996), who used soybean meal, meat and bone meal, and wheat bran, compared with corn. If the residue of samples used by Beckers et al. (1996) was less degradable in the hindgut, more of the degradable protein fraction would be available for samples ruminally incubated for a shorter period of time compared with those that were incubated longer, with the protein associated more tightly with the postruminally indigestible DM residue.

The values used by the current NRC model assume UIP digestibility to be $80 \%$ for all feedstuffs (NRC, 1996). Because UIP from corn provides a large amount of metabolizable protein to finishing cattle, small changes in UIP digestibility can have a large impact on metabolizable protein. Voigt et al. (1985) observed a 7.3 percentage unit increase in UIP digestibility for corn samples recovered in the feces compared with those recovered at the terminal ileum. If the values presented in this study for DRC and HMC are inflated because of hindgut fermentation, the actual UIP digestibility for DRC may be lower than $70 \%$. However, the average UIP digestibility of HMC across samples and incubation times appears similar to current NRC assumptions of $80 \%$ digestibility.

\section{IMPLICATIONS}

Total tract nutrient digestibilities are greater for HMC compared with DRC. Hybrids with softer kernel traits fed as DRC may have greater ruminal STD based on propionate concentrations, which are correlated with kernel hardness. Hybrids with less desirable kernel traits benefit from a more intense processing method to increase STD. Animals consuming HMC and DRC may alter intake patterns to reduce the incidence of subacute acidosis, resulting in a similar average ruminal $\mathrm{pH}$. The particle size for the simulated masticate grind was comparable with animal masticated corn samples when DRC was ground as is and when HMC was ground frozen. The mobile bag technique was useful in determining relative differences among corn 
hybrids and processing methods for postruminal nutrient digestibility.

\section{LITERATURE CITED}

AOAC. 1995. Official Methods of Analysis. 14th ed. Assoc. Off. Anal. Chem., Arlington, VA.

Beckers, Y., A. Thewis, and B. Maudoux. 1996. Intestinal digestibility of rumen undegraded $\mathrm{N}$ of concentrates measured by the mobile nylon bag technique. Anim. Feed Sci. Technol. 61:305.

Behnke, K. C. 1994. Feed Manufacturing Technology IV. American Feed Industry Association Inc., Arlington, VA.

Benton, J. R., T. J. Klopfenstein, and G. E. Erickson. 2005a. Effects of corn moisture and degradable intake protein concentration on finishing cattle performance. Nebraska Beef Report MP 83:28. Univ. of Nebraska, Lincoln.

Benton, J. R., T. J. Klopfenstein, and G. E. Erickson. 2005b. Effects of corn moisture and length of ensiling on dry matter digestibility and rumen degradable protein. Nebraska Beef Report MP 83:31. Univ. of Nebraska, Lincoln.

Britton, B., and V. Krause. 1985. High moisture corn: Effects of type and length of storage. Nebraska Beef Cattle Rep. MP 48:28. Univ. of Nebraska, Lincoln.

Cooper, R. J., T. J. Klopfenstein, R. A. Stock, C. T. Milton, D. W. Herold, and J. C. Parrott. 1999. Effects of imposed feed intake variation on acidosis and performance of finishing steers. J. Anim. Sci. 77:1093.

Cooper, R. J., C. T. Milton, T. J. Klopfenstein, T. L. Scott, C. B. Wilson, and R. A. Mass. 2002. Effect of corn processing on starch digestion and bacterial crude protein flow in finishing cattle. J. Anim. Sci. 80:797.

Corona, L., F. N. Owens, and R. A. Zinn. 2006. Impact of corn vitreousness and processing on site and extent of digestion by feedlot cattle. J. Anim. Sci. 84:3020.

Correa, C. S., R. Shaver, M. Pereira, J. Lauer, and K. Kohn. 2002. Relationship between corn vitreousness and ruminal in situ starch degradability. J. Dairy Sci. 85:3008.

Crawford, G. I., C. D. Keeler, J. J. Wagner, C. R. Krehbiel, G. E. Erickson, M. B. Crombie, and G. A. Nunnery. 2008. Effects of calcium magnesium carbonate and roughage level on feedlot performance, ruminal metabolism, and site and extent of digestion in steers fed high-grain diets. J. Anim. Sci. 86:2998.

Dombrink-Kurtzman, M. A., and J. A. Bietz. 1993. Zein composition in hard and soft endosperm of maize. Cereal Chem. 70:105.

Erickson, G. E., C. T. Milton, K. C. Fanning, R. J. Cooper, R. S. Swingle, J. C. Parrot, G. Vogel, and T. J. Klopfenstein. 2003. Interaction between bunk management and mon- ensin concentration on finishing performance, feeding behavior, and ruminal metabolism during an acidosis challenge with feedlot cattle. J. Anim. Sci. 81:2869.

Erwin, E. S., D. J. Mareo, and E. M. Emery. 1961. Volatile fatty acid analysis of blood and rumen fluid by gas chromatography. J. Dairy Sci. 44:1768.

French, D. 1973. Chemical and physical properties of starch. J. Anim. Sci. 37:1048.

Fulton, W. R., T. J. Klopfensten, and R. A. Britton. 1979. Adaptation to high concentrate diets by beef cattle. I. Adaptation to corn and wheat diets. J. Anim. Sci. 49:775.

Galyean, M. L., D. G. Wagner, and F. N. Owens. 1981. Dry matter and starch disappearance of corn and sorghum as influenced by particle size and processing. J. Dairy Sci. 64:1804.

Haugen, H. L., S. K. Ivan, J. C. MacDonald, and T. J. Klopfenstein. 2006. Determination of undegradable intake protein digestibility of forages using the mobile nylon bag technique. J. Anim. Sci. 84:886.

Huntington, G. B. 1997. Starch utilization by ruminants: From basics to the bunk. J. Anim. Sci. 75:852.

Jaeger, S. L., M. K. Luebbe, C. N. Macken, G. E. Erickson, T. J. Klopfenstien, W. A. Fithian, and D. S. Jackson. 2006. Influence of corn hybrid traits on digestibility and the efficiency of grain in feedlot cattle. J. Anim. Sci. $84: 1790$

Klopfenstein, T. J., R. A. Mass, K. W Creighton, and H. H. Patterson. 2001. Measuring forage protein degradability in the rumen. J. Anim. Sci. 79:E208.

Krehbiel, C. R., R. A. Stock, D. W. Herold, D. H. Shain, G. A. Ham, and J. E. Carulla. 1995. Feeding wet corn gluten feed to reduce subacute acidosis in cattle. J. Anim. Sci. 73:2931

Ladely, S. R., R. A. Stock, F. K. Goedeken, and R. P. Huffman. 1995. Effect of corn hybrid and grain processing method on rate of starch disappearance and performance of finishing cattle. J. Anim. Sci. 73:360.

Littell, R. C., P. R. Henry, and C. B. Ammerman. 1998. Statistical analysis of repeated measures data using SAS procedures. J. Anim. Sci. 76:1216.

Lopez, S., F. D. Hovell, B. Manyuchi, R. I. Smart. 1995. Comparison of sample preparation methods for the determination of the rumen degradation characteristics of fresh and ensiled forages by the nylon bag technique. Anim. Sci. 60:439.

Loveday, D. M., H. C. Block, P. A. Thacker, and J. J. McKinnon. 2006. Factors affecting the apparent intestinal (small and large) disappearance of dry matter and crude protein from rumen undegradable residues of various feeds determined using the mobile bag technique for cattle. Can. J. Anim. Sci. 86:419.
Macken, C. N. 2004. Optimizing corn use by finishing cattle through wet corn milling by-products and corn processing. PhD Diss. Univ. Nebraska, Lincoln.

Macken, C. N., G. E. Erickson, C. T. Milton, T. J. Klopfenstein, and H. Block. 2003. Effects of starch endosperm type and corn processing method on feedlot performance, nutrient digestibility and ruminal fermentation of high-grain diets. Nebraska Beef Report MP 80:32. Univ. of Nebraska, Lincoln.

Murphy, T. A., F. L. Fluharty, and S. C. Loerch. 1994. The influence of intake level and corn processing on digestibility and ruminal metabolism in steers fed all concentrate diets. J. Anim. Sci. 75:1608.

NRC. 1996. Nutrient Requirements of Beef Cattle. 7th ed. Natl. Acad. Press, Washington, DC.

NRC. 2001. Nutrient Requirements of Dairy Cattle. 7th ed. Natl. Acad. Press, Washington, DC.

Owens, F. N., and C. F. Hanson. 1992.

External and internal markers for appraising site and extent of digestion in ruminants. J. Dairy Sci. 75:2605.

Owens, F. N., D. S. Secrist, W. J. Hill, and D. R. Gill. 1997. The effect of grain source and grain processing on performance of feedlot cattle: A review. J. Anim. Sci. 75:868.

Owens, F. N., D. S. Secrist, W. J. Hill, and D. R. Gill. 1998. Acidosis in cattle: A review. J. Anim. Sci. 76:275.

Owens, F. N., and R. A. Zinn. 2005. Corn grain for cattle: Influence of processing on site and extent of digestion. Southwest Nutr. Manage. Conf., Tempe, AZ.

Owens, F. N., R. A. Zinn, and Y. K. Kim. 1986. Limits to starch digestion in the ruminant small intestine. J. Anim. Sci. 63:1634

Philippeau, C., J. Landry, and B. MichaletDoreau. 1998. Influence of the biochemical and physical characteristics of the maize grain on ruminal starch degradation. J. Agric. Food Chem. 46:4287.

Philippeau, C., F. Le Deschault, and B. Michalet-Doreau. 1999a. Relationship between ruminal starch degradation and the physical characteristics of corn grain. J. Anim. Sci. $77: 238$.

Philippeau, C., C. Martin, and B. MichaletDoreau. 1999b. Influence of grain source on ruminal characteristics and rate, site and extent of digestion in beef steers. J. Anim. Sci. 77:1587.

Philippeau, C., and B. Michalet-Doreau. 1997. Influence of genotype and stage of maturity or rate of ruminal starch degradation. Anim. Feed Sci. Technol. 68:25.

Prigge, E. C., R. R. Johnson, F. N. Owens, and D. Williams. 1976. Soluble nitrogen and acid production of high moisture corn. J. Anim. Sci. 42:490. 
Raun, N. S., and W. Burroughs. 1962. Suction strainer technique in obtaining rumen fluid samples from intact lambs. J. Anim. Sci. 21:454.

Remond, D., J. I. Caberera-Estrada, M. Champion, B. Chauveau, R. Coudure, and C. Poncet. 2004. Effect of corn particle size on site and extent of starch digestion in lactating dairy cows. J. Dairy Sci. 87:1389.

Rooney, L. W., and R. L. Pflugfelder. 1986. Factors affecting starch digestibility with special emphasis on sorghum and corn. J. Anim. Sci. 63:1607.

Secrist, D. S., W. J. Hill, F. N. Owens, and S. D. Welty. 1995. Effects of corn particle size on feedlot steer performance and carcass characteristics. Oklahoma Anim. Sci. Res. Rep. MP-943:99. Oklahoma State Univ., Stillwater.

Shain, D. H., R. A. Stock, T. J. Klopfenstein and D. W. Herold. 1999. The effect of forage source and particle size on finishing yearling steer performance and ruminal metabolism. J. Anim. Sci. 77:1645.
Simon, J. J. 2001. Effects of particle size and mastication on starch digestion. MS Thesis. Univ. of Nebraska, Lincoln.

Stock, R. A., D. R. Brink, R. A. Britton, F. K. Goedeken, M. H. Sindt, K. K. Kreikemeier, M. L. Bauer, and K. K. Smith. 1987. Feeding combinations of high moisture corn and dry-rolled grain sorghum to finishing steers. J. Anim. Sci. 65:290.

Stock, R. A., M. H. Sindt, R. M. Cleale, and R. A. Britton. 1991. High-moisture corn utilization in finishing cattle. J. Anim. Sci. 69:1645.

Szasz, J. I., C. W. Hunt, P. A. Szasz, R. A. Weber, F. N. Owens, and W. Kezar. 2005.

Influence of Endosperm Vitreousness and Kernel Moisture on Site and Extent of Digestion of High Moisture Corn by Steers. Plains Nutrition Council Rep. AREC 05-20. Texas A\&M Univ., Amarillo.

Szasz, J. I., C. W. Hunt, P. A. Szasz, R. A. Weber, F. N. Owens, W. Kezar, and O. A. Turgeon. 2007. Influence of endosperm vitreousness and kernel moisture at harvest on site and extent of digestion of high-moisture corn by feedlot steers. J. Anim. Sci. 85:2214.

Theurer, B. A. 1986. Grain processing effects on starch utilization by ruminants. J. Anim. Sci. 63:1649.

Vanzant, E. S., R. C. Cochran, and E. C. Titgemeyer. 1998. Standardization of in situ techniques for ruminal feedstuff evaluation. J. Anim. Sci. 76:2717.

Voigt, J., B. Piatkowski, H. Engelmann, and E. Rudolph. 1985. Measurement of the postruminal digestibility of crude protein by the bag technique in cows. Arch. Tierernaehr. Berlin 33:555.

Whittet, K. M., K. W. Creighton, K. J. Vander Pol, G. E. Erickson, and T. J. Klopfenstein. 2003. Influence of rinsing technique and sample size on in situ protein degradation. Nebraska Beef Report MP 80-A:86. Univ. of Nebraska, Lincoln.

Williams, C. H., D. J. David, and O. Ismaa. 1962. The determination of chromic oxide in faeces by atomic absorption spectrophotometry. J. Agric. Sci. 59:381. 